\title{
Changes in Plant Diversity and Composition across Forest Edges Bordered by Austroeupatorium inulifolium Invaded Grasslands in the Knuckles Conservation Area, Sri Lanka
}

\author{
N. Haluwana and H. M. S. P. Madawala* \\ Department of Botany, University of Peradeniya, Peradeniya, Sri Lanka. \\ Accepted December 22, 2013
}

\begin{abstract}
Austroeupatorium inulifolium has become a ferocious invader over the years in many ecosystems in the wet zone of Sri Lanka, including the grasslands of the Knuckles Conservation Area (KCA). Two field studies were conducted to assess the impacts of Austroeupatorium invasion on the diversity and composition of the plant communities. In the first study, three habitat categories were identified: less-invaded grassland (LIG), highly-invaded grassland (HIG) and the forest-grassland edge (FGE) adjacent to HIG. In the second study, two transects were selected that run across the FGE bordered by less or highly invaded grasslands (FGELIG and FGE-HIG). At each community, 5 linear quadrats (12 m x $3 \mathrm{~m}$ ) were laid parallel to the FGE at different distances away from the edge to the forest interior and the open grassland. Each quadrat was further sub-divided into 3 quadrats. Three such transects were studied for each community. In both studies, the vegetation less than $2 \mathrm{~m}$ in height was enumerated. The stem density and abundance of Austroeupatorium were significantly higher in HIG and FGE compared to LIG. However, the plant community at FGE was less diverse than that of HIG and LIG. Tree saplings were observed only in the HIG, suggesting its favourable conditions for their establishment. The abundance of Austroeupatorium was markedly reduced towards the forest interior, suggesting that the FGE acts as a barrier against invasion towards the forest. The tree sapling abundance decreased from the forest interior towards the open grassland but the abundance was higher in transects bordered by HIG than by LIG. This suggests a facilitative effect on the forest tree regeneration potential under the Austroeupatorium canopy. The invasion may have led to improved microclimatic and edaphic conditions, which perhaps facilitated the tree seedling establishment and survival in the forest interior as far as $10 \mathrm{~m}$ away from the FGE. Current findings depict positive impacts of Austroeupatorium-invaded grasslands on the forest regeneration process. Therefore, it is time to explore the positive effects of exotic species, especially when they colonize highly degraded landscapes, rather than generalizing that all invasive species cause detrimental impacts on every landscape.
\end{abstract}

Keywords: forest regeneration, forest-grassland edge, invaded grasslands

\section{INTRODUCTION}

Throughout the tropics, large expanses of forests have been fragmented into small, isolated forest patches mainly due to anthropogenic activities. Abrupt forest edges expose forest interior to external influences, making forests vulnerable to external impacts. The biotic and abiotic factors and their interactions along these forest edges are termed as 'edge effects' (Murcia, 1995). Significant compositional changes have been shown to occur in the understory vegetation over time along these edges (Harper and Macdonald, 2002). Such alterations may eventually cause significant impacts on the inherent structure and composition of these forest patches.
Microclimatic parameters (light intensity and duration, soil and air temperatures, wind action, relative humidity) along these forest edges vary widely compared to the forest interior (Lovejoy et al. 1986; Brothers \& Spingarn 1992). Such changes could affect plant communities that survive in the forest interior as well as along forest edges. Studies have reported greater tree mortality rates, changes in vegetation structure and reduction in woody seedlings (BenitezMalvido, 1998; Laurance, 2000; Honnay et al., 2002), alien plant invasions (Saunders et al., 1991; Brothers and Spingarn, 1992; Pauchard and Alaback, 2006), and loss of biodiversity (Gascon et al., 2000; Laurance et al., 2002; Harper et al., 2005) due to edge effects.

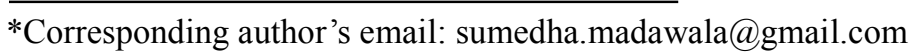


Alien invasive species alter ecosystem structure and function dramatically (Vitousek et al. 1997). Invasion of non-forest species into forest interiors is considered as one of the most negative ecological consequence of edge effects (Lin and Cao 2009). The forest edge can act as a potential starting point for invasion of alien plant species into less-disturbed forest interior (Honnay et al. 2002; Cadenasso and Pickett, 2001; Borgmann and Rodewald, 2005; Pauchard and Alaback, 2006). This situation could even become more severe when the forest edge is bordered by a highly invaded landscape. However, studies have shown that invasive plants are often unable to percolate deep into the forest interior as they require high light and nutrients that are best provided along the edge environments (Watkins et al., 2003 and Pauchard and Alaback 2006). Others suggest that the chance of spreading nonforest species into forest interior depend on the edge characteristics and the type of adjoining landscape (Brothers and Spingarn 1992). Smaller forest fragments are more vulnerable to species invasion than are larger fragments (Raghubanshi and Thripathi 2009). A study in Vindhyan dry deciduous forests in India observed a clear decreasing trend in density and species richness with increasing Lantana cover (Sharma, 2007).

Hobbs and Huenneke (1992) pointed out that the increase in plant richness along edges due to fragmentation is an appealing consequence from the perception of conservation management. However, studies also demonstrated that groups of plants that inhabit edge communities are mainly belong to alien invasive, weedy, disturbance-tolerant and pioneer forest species (King and Buckney, 2001; Honnay et al., 2002; Gehlhausen et al., 2000; Oosterhoorn and Kappelle, 2000), rather than forest tree species. It is also noted that the decreasing patch size along with increasing borderline length may enhance the degree of influence from the adjoining vegetation type (Jacquemyn et al., 2001, Devlaeminck et al., 2005). The degree of influence is even more critical when the forest stand is bordered by agricultural lands (Cadenasso and Pickett 2001, Honnay et al., 2002). Therefore, it can be hypothesized that bordering landscape can have a decisive impact on the edge characteristics and their associated influence on the vegetation structure and composition.

Over the last few years, many landuse types in the Knuckles Conservation Area (KCA) have been rapidly invaded by Austroeupatorium inulifolium, a known invasive shrub worldwide (Hsu et al.,
2006). From these different landuse types, the degraded grasslands are the most vulnerable for the Austroeupatorium invasion. However, the coverage of Austroeupatorium invasion is highly variable on these grasslands, where some areas (near Pitawala patana) are highly invaded while others sparsely invaded. The cause of this uneven distribution is not known. In KCA, the lowermontane forest remnants are often demarcated by these highly degraded, invasive grasslands. Field observations verify that these forest-grassland boundaries are noticeably invaded by Austroeupatorium, indicating a possibility of expanding its range into the forest interior. In spite of well known negative impacts of exotic invasions, some positive feedbacks of such invasions on highly degraded landscape can also be speculated. Providing a thick cover to these exposed highly degraded grasslands may have improved the micro-habitat conditions thereby facilitating the establishment of forest tree species. This study investigated how an edge between lower-montane forest and an adjacent grassland invaded by Austroeupatorium could influence the structure, richness, abundance and composition of the forest undergrowth across forest-grassland edges. The following questions guided our research: (1) Does Austroeupatorium invasion alter the vegetation structure and composition of the forest interior and the grassland? (2) Does Austroeupatorium invasion in the grassland favour forest expansion towards the grassland?

\section{MATERIALS AND METHODS}

\section{Field sites and Sampling design}

All field sites were selected from Riverston and Pitawala areas located within KCA. Two vegetation studies have been carried out. In the first study, three different plant communities were identified based on the extent of Austroeupatorium invasion: less-invaded and highly-invaded grasslands (hereafter termed as LIG and HIG respectively), and forest-grassland edge (FGE) located next to a HIG. The sites have not been affected by fire in recent years. In each of these three communities, six $4 \mathrm{~m}^{2}$ quadrats (2 quadrats from 3 blocks) were used to enumerate their vegetation (a total of $72 \mathrm{~m}^{2}$ area was sampled for all three plant communities). The quadrats in the LIG and HIG communities were randomly placed approximately $30 \mathrm{~m}$ away from forest remnants nearby, while in the FGE community the quadrats were placed within a $5 \mathrm{~m}$ range from the forest-grassland edge. In each 
quadrat, all plants less than $2 \mathrm{~m}$ in height were recorded and identified to their species level. The cover values were also recorded for most dominant species.

In the second study, six transects ( 2 from each block) from two grassland communities (less- and highly-invaded grasslands) bordering the lowermontane forest patches were sampled (hereafter termed as FGE-LIG and FGE-HIG respectively). In each transect laid across the forest-grassland border, 5 linear quadrats $(3 \mathrm{~m} \mathrm{x} 12 \mathrm{~m})$ were placed parallel to the FGE at different distances; 0 (edge), 5 and $10 \mathrm{~m}$ away from the edge towards the grassland and towards the forest interior (Figure 1). Each $36 \mathrm{~m}^{2}$ quadrat was further divided into three sub-plots $\left(3 \times 12 \mathrm{~m}^{2}\right)$, where all plants less than $2 \mathrm{~m}$ in height were enumerated. A total of $540 \mathrm{~m}^{2}$ area was sampled from each forest-grassland edge community. The percentage cover and density of each plant species (belonged to different life forms such as tree saplings, shrubs, herbs and graminoids) was recorded.

\section{Data analysis}

All data were subjected to normality test before applying statistics. The General Linear Model (GLM) was used to analyze data, considering distance as a fixed factor. Mean separation was done using Tukey's test. Data was analyzed using Minitab version 16.

\section{RESULTS}

\section{Field study 1}

As envisaged, stem density and number of individuals of Austroeupatorium were significantly higher in the HIG and FGE habitats than that in the LIG habitat $(F=3.89 ; P<0.05$; $F=3.62: P<0.05$ respectively; Table 1$)$. Percentage cover values too showed a similar trend: the HIG and FGE values being significantly higher than the LIG values $(F=$ 4.10; $P<0.05$ ). However, average plant height of Austroeupatorium did not vary significantly among the three sites (Table $1 ; \mathrm{F}=0.748 ; P=$ 0.489).

\section{Vegetation structure and composition} In the vegetation survey, 2,048 individuals representing, 39 species and 3 morphospecies (un-identified) of vascular plants were enumerated (Appendix 1). Of the total number of individuals sampled, 350 (17\%), 388 (19\%) and $1,310(19 \%)$ were recorded in the HIG, LIG and FGE communities, respectively.

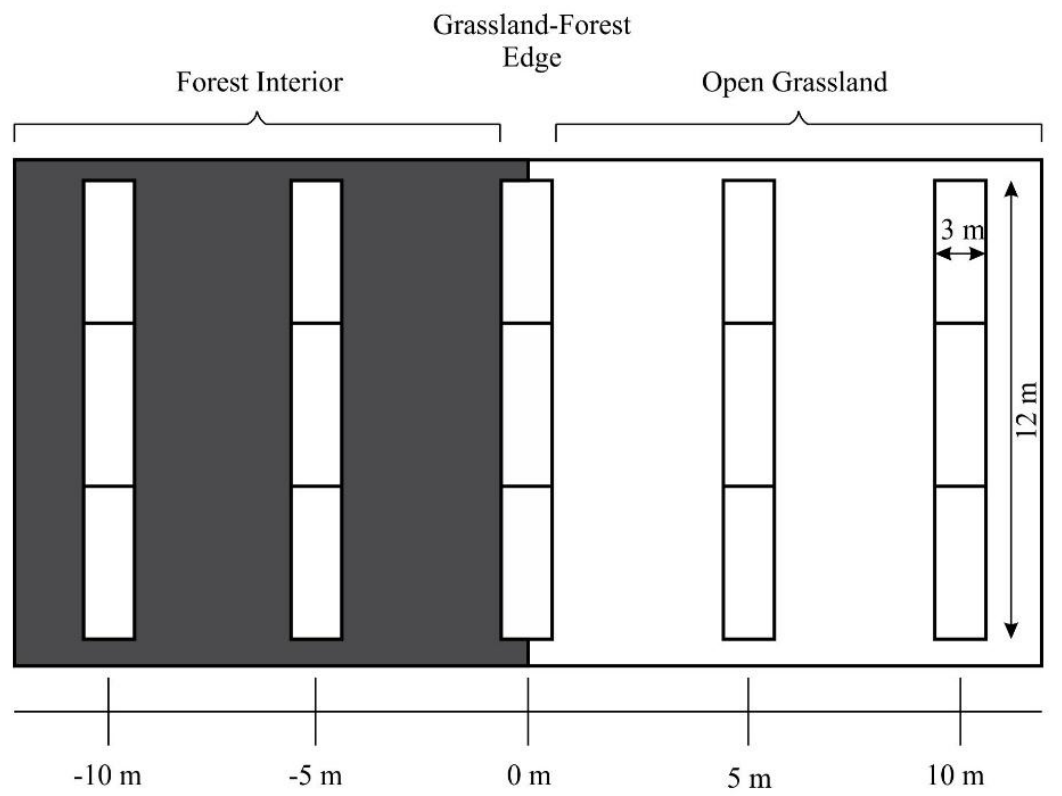

Figure 1. Layout of the five quadrats (each $3 \mathrm{~m} \mathrm{x} 12 \mathrm{~m}$ ) parallel to the forest-grassland edge in one of the six transects sampled in the second study to quantify the vegetation across the forest-grassland edge at Knuckles Conservation Area, Sri Lanka. Transect was placed along the forest grassland gradient and quadrats were demarcated at 0 representing the forest-grassland edge, at $-5 \mathrm{~m}$ and $-10 \mathrm{~m}$ towards the forest interior and at $5 \mathrm{~m}$ and $10 \mathrm{~m}$ towards the open grassland, to sample the respective communities. 
Table 1. The contribution of Austroeupatorium inulifolium in the three different plant communities, lessinvaded grassland (LIG), highly-invaded grassland (HIG) and forest-grassland edge (FGE) sampled at Riverston in the Knuckles Conservation Area, Sri Lanka. Shannon-Weiner Indices of LIG, HIG and FGE were calculated taking into consideration the total vegetation data including A. inulifolium. Different letters indicate significant differences among values.

\begin{tabular}{lccc}
\hline & \multicolumn{3}{c}{ Communities } \\
\cline { 2 - 4 } & $\begin{array}{c}\text { Less-invaded } \\
\text { grassland (LIG) }\end{array}$ & $\begin{array}{c}\text { Highly-invaded } \\
\text { grassland (HIG) }\end{array}$ & $\begin{array}{c}\text { Forest-grassland } \\
\text { Edge (FGE) }\end{array}$ \\
\hline Austroeupatorium inulifolium & & & \\
Stem density/4 sq.m & $7.3^{\mathrm{b}}$ & $19.8^{\mathrm{a}}$ & $25.3^{\mathrm{a}}$ \\
Number of individuals/4 sq.m & $1.5^{\mathrm{b}}$ & $5.2^{\mathrm{a}}$ & $6.0^{\mathrm{a}}$ \\
Average height (cm) & $126.9^{\mathrm{a}}$ & $130.5^{\mathrm{a}}$ & $107.4^{\mathrm{a}}$ \\
Cover (\%) & $30^{\mathrm{b}}$ & $80^{\mathrm{a}}$ & $60^{\mathrm{a}}$ \\
\hline & & 2.77 & 1.66 \\
Shannon-Weiner Diversity Index & 2.48 & & \\
\hline
\end{tabular}

A total of 30 species in 20 families were identified in the highly-invaded grassland (HIG), while 21 species in 14 families were indentified in the lessdensely invaded grasslands (LIG) and in the forest-grassland edge (FGE), 14 species in 9 families were identified. Tree saplings (Symplocos cochinchinensis, Eleagnus sp., Maesa indica and Marcaranga peltata) were found only in the HIG community. The number and proportion (\% relative to species richness per community) of exotic invasive species was 4 $(13 \%)$ in the HIG community, $2(10 \%)$ in the LIG community and in the FGE community only 1 (7\%), viz., Austroeupatorium.

Fifteen species that were recorded in the HIG were absent in the other two habitats, including Symplocos cochinchinensis, Maesa indica, Macaranga peltata, Eleganus sp., Lantana camara, Sida cordifolia, Oxalis sp. and Hedyotis $s p$. Out of the 39 species identified in the survey, only 7 viz., Austroeupatorium inulifolium, Osbeckia octandra, Desmodium triflorum, Stachytarpheta indica, Centella asiatica, Cymbopogon nardus and Axonopus compressus, were found in all three habitats.

The abundance of all life forms, except tree saplings, was significantly higher in the FGE community compared to either of the Austroeupatorium-invaded grasslands, LIG and HIG (Figure 2). In contrast, species richness in each life form group showed no significant difference among the three plant communities. However, the Shannon-Weiner Diversity Index was higher in HIG compared to that of LIG and FGE habitats (Table 1). In spite of the low plant abundance, LIG showed greater diversity than in FGE (Figure 1 and Table1).

\section{Field study 2}

Austroeupatorium invasion from grassland to the forest interior

In both forest-grassland boundary communities (FGE-LIG and FGE-HIG), Austroeupatorium abundance increased towards the open grassland, and this trend was highly evident in the FGE-HIG community than in the FGE-LIG community (Figure 3). Furthermore, the forest interior of the less-invaded grasslands had fewer Austroeupatorium individuals (only one individual at $-10 \mathrm{~m}$ distance) in contrast to forest remnants bordered by highly-invaded grasslands.

\section{Vegetation composition}

During the survey, 6,361 individuals were recorded in transects bordered by highly-invaded grasslands (FGE-HIG) and 3,479 individuals across FGE-LIG. Of the 6,361 individuals, 430 $(6.7 \%)$ were tree saplings, $780(12.3 \%)$ shrub, 3645 (57.3\%) herbaceous and 1506 (23.8\%) graminoids were observed in FGE-HIG. These individuals represented 46 species: 14 tree-, 8 shrub-, 21 herbaceous- and 3 graminoid species. In the FGE-LIG, the 3,479 individuals represented $182(5.2 \%)$ tree saplings, 964 (27.7\%) shrubs, 1677 (48.2\%) herbs and 656 (18.8\%) graminoids; these plants belonged to 37 different species: 11 tree-, 7 shrub-, 15 herb- and 3 graminoid species (Appendix 1). 
(A)

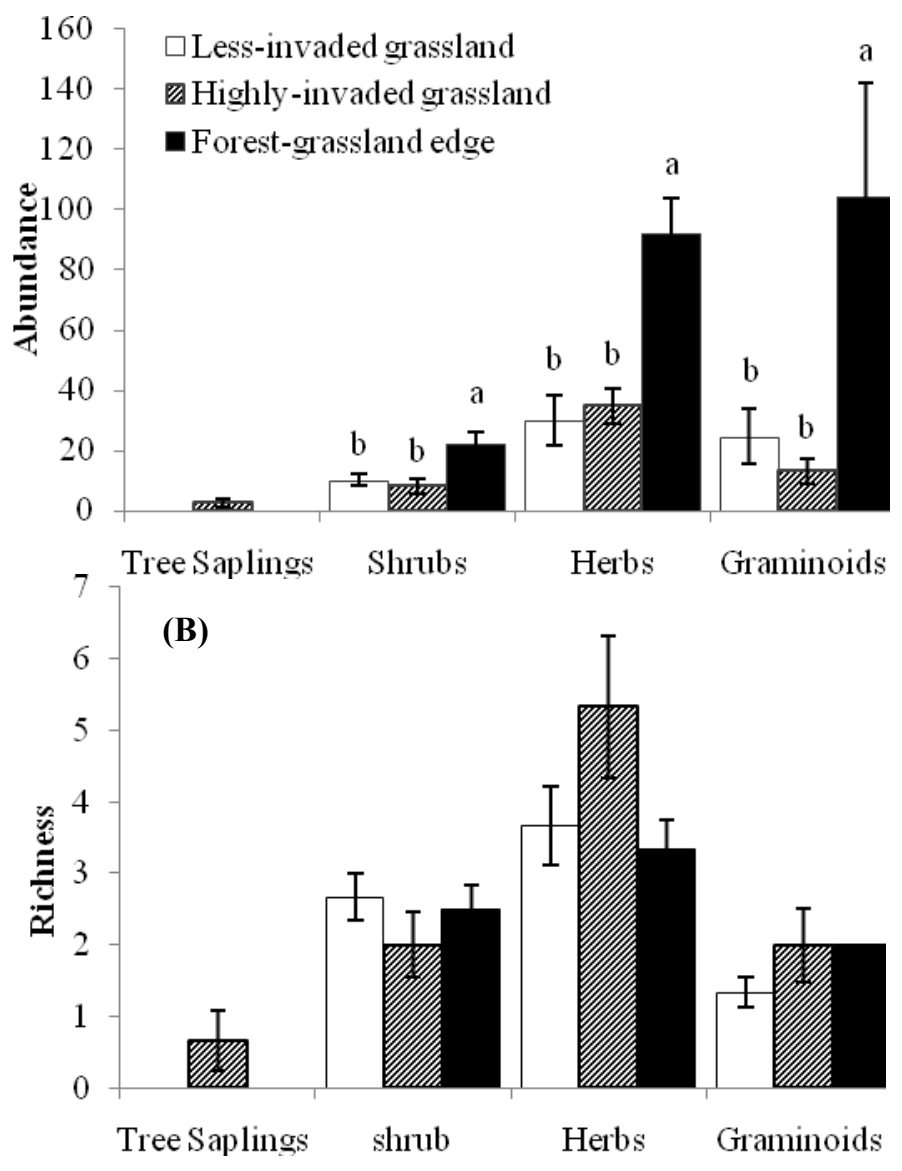

Figure 2. Abundance (A) and species richness (per 4 sq. m) (B) of different life forms (plants less than 2 height) in the three plant communities, less-invaded (LIG) and highly-invaded (HIG) grasslands by Austroeupatorium, and the forest-grassland edge (FGE), studied at Riverston, in the Knuckles Conservation Area, Sri Lanka. Different letters given in graph A indicate significant differences observed in each life form among plant communities. No significant differences were observed in graph B.

Of the tree saplings encountered in FGE-LIG (182) and FGE-HIG (430) communities, a majority were found in quadrats laid in the forest interior (76 and $88 \%$ respectively), while edge quadrates had 20 and $9 \%$ and grassland quadrats had 4 and 3\% respectively (Figure 4 ). The tree sapling distribution was highly patchy in the open grassland. Of the 964 and 780 individuals of shrub species in FGE-LIG and FGE-HIG respectively, 59\% were encountered in the open grasslands at FGE-LIG, and 55\% was in the FGEHIG. In contrast to tree saplings, in both habitats, a majority of individuals of herbaceous and graminoid species were encountered in open grasslands.

In both FGE-LIG and FGE-HIG communities, the abundance of tree saplings showed an increasing trend from open grassland towards the interior of the forest (Figure 5, ANOVA: $\mathrm{F}=$ $17.31, \mathrm{p} \leq 0.001)$. Interestingly, this trend was more conspicuous at FGE-HIG than in FGE-LIG. At FGE-HIG, the tree sapling abundance was significantly higher at $-10 \mathrm{~m}$ than that of FGELIG (ANOVA: $\mathrm{F}=10.71, \mathrm{p}=002$ ).

In contrast to the trends observed with tree saplings, the shrub abundance showed an increasing trend away from the forest-edge towards the open grassland in both habitats (Figure 5). However, the shrub abundance showed no significant difference between the two habitat categories at different distances (ANOVA: $\mathrm{F}=1.04, \mathrm{p}=0.312$ ). Even though no significant differences were observed, the forest fragments bordered by LIG had higher abundance of shrubs towards the open grassland compared to the forest bordered by highly-invaded grasslands. 
Correspondingly, both herbs and graminoids also increased towards the open grassland. The abundance of herbaceous plants was greater in the FGE-HIG than in the FGE-LIG, with a significant difference at $5 \mathrm{~m}$ (ANOVA: $\mathrm{F}=9.62, \mathrm{p}=0.003$ ). Herbs and graminoids showed drastic reductions in their abundance from the forest-grassland edge towards the interior of the forest and this effect was more pronounced at the FGE-HIG than at the
FGE-LIG. Abundance of graminoids was significantly higher in the grassland transects of the FGE-HIG than those in the FGE-LIG community, but decreased towards the forest interior in both communities (ANOVA: $\mathrm{F}=13.28$, $\mathrm{p} \leq 0.001)$. All life forms except shrubs showed significant interaction effect between habitat and distance.

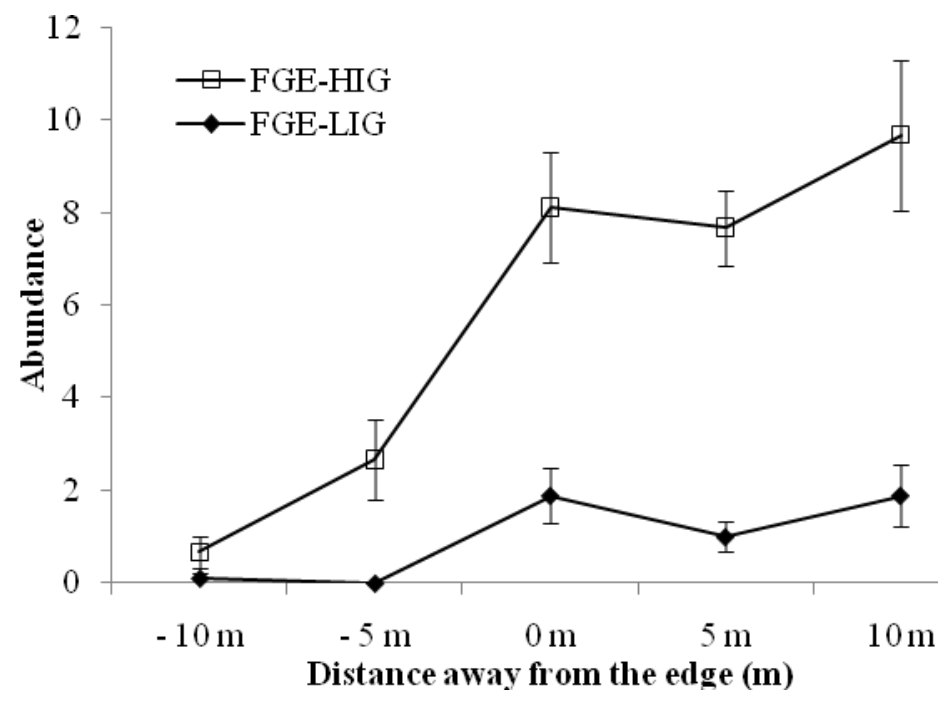

Figure 3. The abundance of Austroeupatorium inulifolium (per 4 sq. m) at different distances away from the forest-grassland edge, where quadrates were demarcated at 0 representing the forest-grassland edge, at $5 \mathrm{~m}$ and $-10 \mathrm{~m}$ towards the forest interior and at $5 \mathrm{~m}$ and $10 \mathrm{~m}$ towards the open grassland, to sample the respective communities.
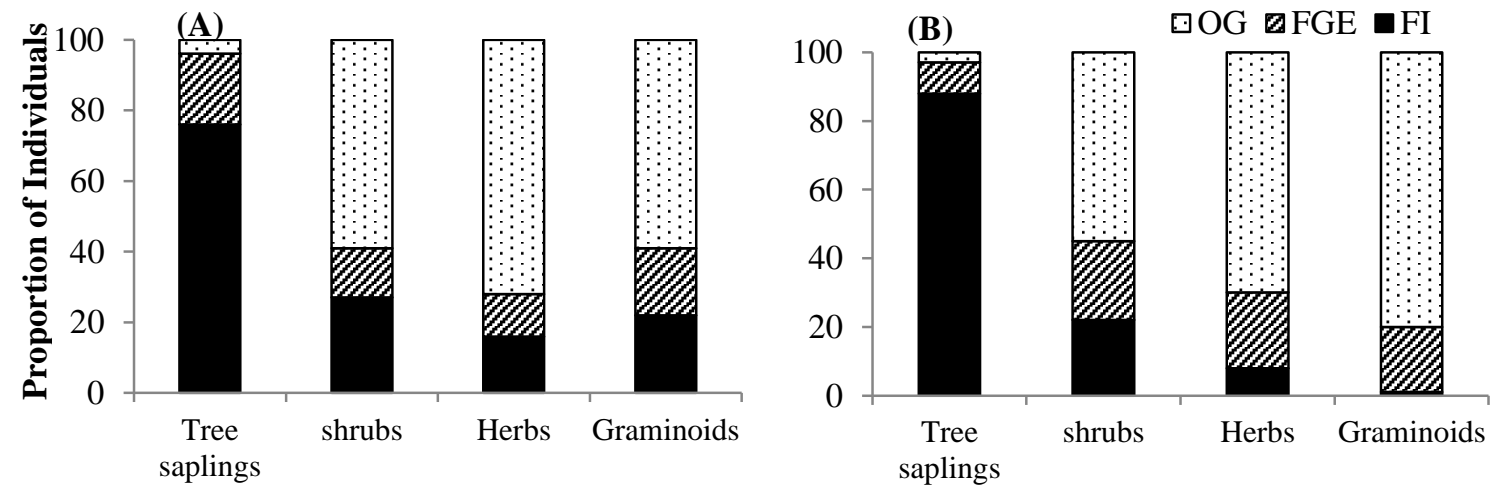

Figure 4. Proportion of individuals as a percentage (less than $2 \mathrm{~m}$ in height) in trees, shrubs, herbs graminoids in relation to the total number of individuals per life form sampled in transects in the forest interior (FI: $-10 \mathrm{~m}$ and $-5 \mathrm{~m}$ quadrates were pooled together), forest-grassland edge (FGE: $0 \mathrm{~m}$ ) and open grassland (OG: pooled data for $5 \mathrm{~m}$ and $10 \mathrm{~m}$ quadrates), in each of the communities, FGE-LIG (A) and FGE-HIG (B). 

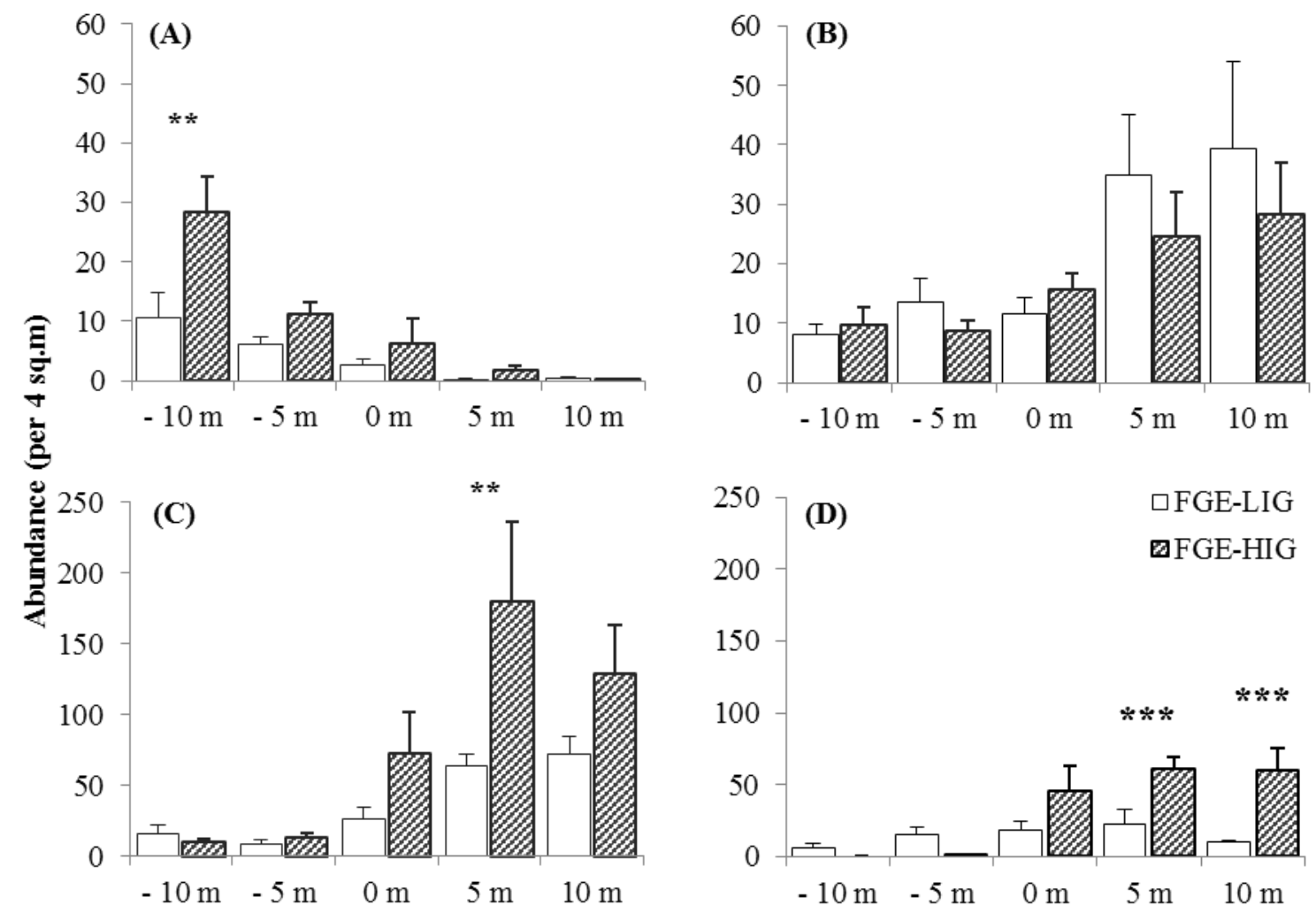

Figure 5. Abundance (per 4 sq. m) of (A) tree saplings, (B) shrubs, (C) herbs and (D) graminoids at different distances either side from the forest-grassland edge in Field Study 2 carried out at Riverston in the Knuckles Conservation Area, Sri Lanka. Asterisks above columns indicate the level of significance $(* \mathrm{p}<0.05$; $* * \mathrm{p}$ $<0.01$ and $* * * \mathrm{P}<0.001)$ similar distances in the FGE-LIG and FGE-HIG habitats.

Tree sapling species richness showed a similar trend to its abundance across the forest-grassland edge in both plant communities. In FGE-HIG, tree sapling species richness was significantly higher at $-10 \mathrm{~m}$ distance compared to that of FGELIG community (ANOVA: $F=27.51, p \leq 0.001$ ). In both plant communities, tree sapling richness decreased from the forest interior towards the open grassland, and this tendency was more marked in the FGE-HIG (Figure 6). Though not significant, the species richness of herbs, shrubs and graminoids were greater in the grassland than in the forest interior in both habitats. Apart from $-5 \mathrm{~m}$ distance, both habitat types showed almost comparable shrub richness across the forestgrassland boundary. The richness of graminoids was significantly higher in the open grassland at FGE-HIG, and then a marked decline towards the interior of the forest (ANOVA: $\mathrm{F}=.9 .87, \mathrm{p}=$ 0.002 for Habitat and $F=26.8, p \leq 0.001$ for distance).

The abundance of endemic, native and exotic species in the understory vegetation of the forest interior was lower compared to their corresponding values in the open grassland (Figure 7). However, the abundances of native and exotic species were significantly higher in the HIG than those of LIG. In contrast, abundance of endemic species was significantly higher in the LIG compared to HIG.

Species richness of natives, exotics (including Austroeupatorium) or endemics showed no significant differences at the forest-grassland edge whether bordered by LIG or HIG. However, native species richness were higher in the forest interior bordered by HIG compared to the forest patches bordered by LIG. A similar trend was observed for exotic species (Figure 7). As for the abundance values, endemic species richness showed higher values in the open grasslands lessinvaded by Austroeupatorium than that in the highly-invaded grasslands. 
(A)

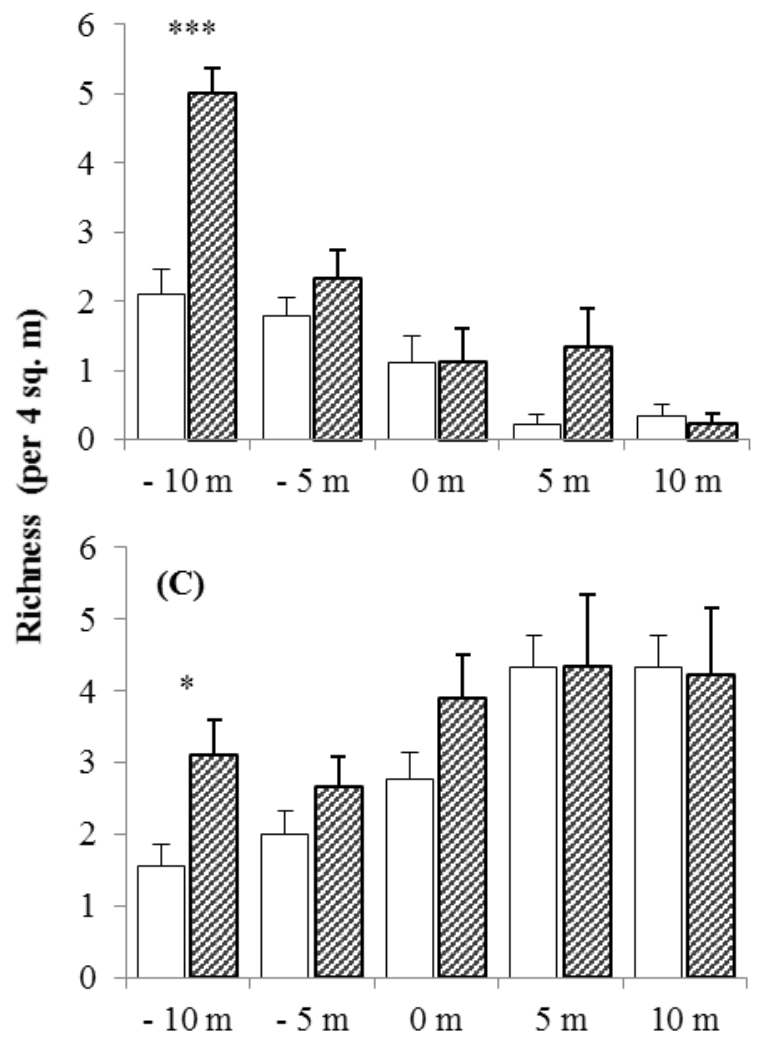

(B)

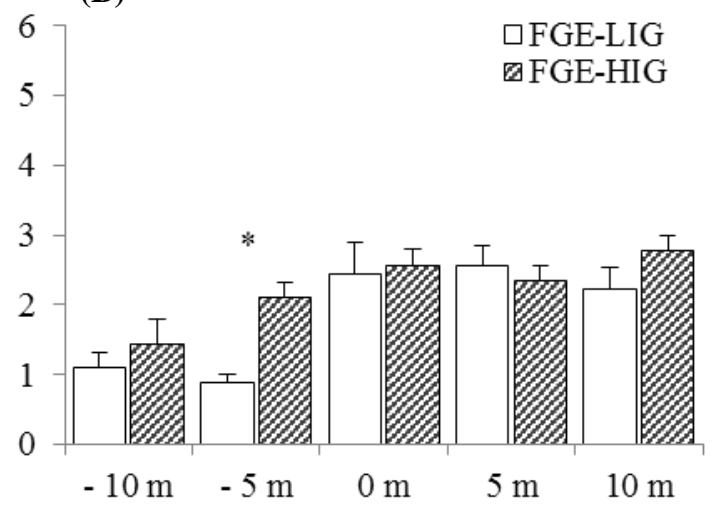

(D)

Figure 6. Richness of (A) forest saplings, (B) shrub, (C) herb and (D) graminoids at different distances away from forest-grassland edges across less- and highly-invaded grasslands FGE-LIG and FGE-HIG respectively). Asterisks above columns indicate the level of significance $(* \mathrm{p}<0.05 ; * * \mathrm{p}<0.01$ and $* * * \mathrm{P}$ $<0.001)$ between the two habitat categories at each distance. The significant differences between distances were not marked to enhance the clarity of the graph. The study was performed at the Knuckles Conservation Area, Sri Lanka.

\section{DISCUSSION}

In Field Study 1 we observed a clear difference in the extent of Austroeupatorium invasion in Cymbopogon-dominated grasslands at KCA. In spite of similarities observed in the extent of Austroeupatorium spread in the FGE and HIG communties, the forest-grassland edge (FGE) had the most populous vegetation among the three plant communities studied. Despite its low plant abundance, the HIG had the highest diversity, compared to that of the other two communities, indicating the positive influence of the Austroeupatorium invasion on the vegetation diversity in the grassland. This claim is further supported by the presence of tree saplings found only in the HIG community and absent in the HIL and FGE communities.
Dense growth of Austroeupatorium may have provided a shielding effect against intense radiation and heat loading which is otherwise common in open grasslands, thereby possibly facilitating colonization by other species. This kind of 'nurse effect' by rapidly growing invasive species has been observed by other workers (Parrotta and Turnbull, 1997; Lugo, 2004). Higher plant abundance at FGE community is probably due to more favourable micro-climatic conditions for plant growth compared to that in the open grasslands. However, regardless of low plant abundance, the HIG community showed the highest diversity among other communities studied indicating its regeneration potential through enhanced micro-habitat conditions. 

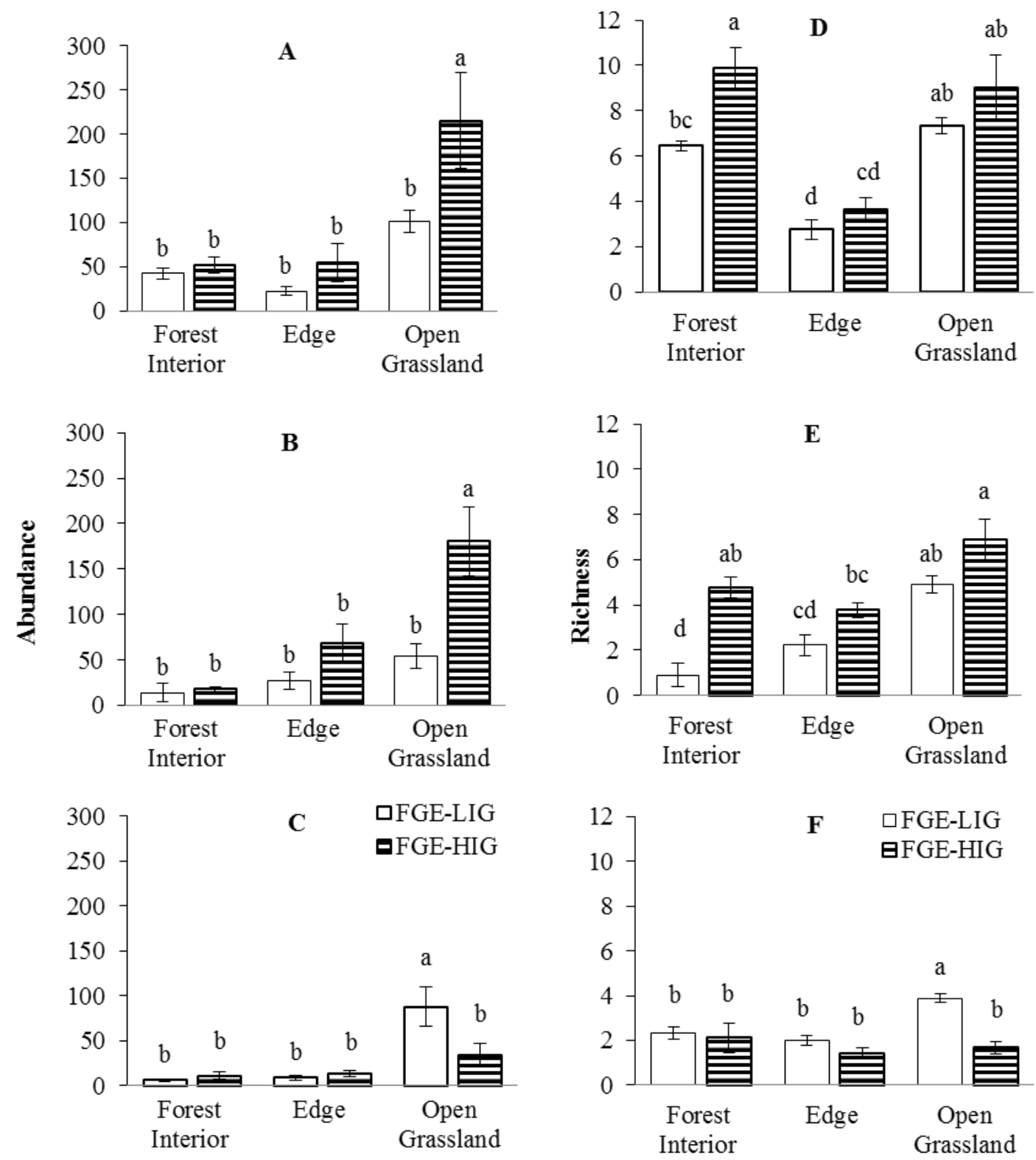

Figure 7. Abundance (A-C) and richness (D-F) of native, exotic and endemic plant species at different habitats (forest interior, edge and open grassland) at the Knuckles Conservation Area, Sri Lanka. Data from -5 and $-10 \mathrm{~m}$ pooled together to represent forest interior while 5 and $10 \mathrm{~m}$ distances together considered as open grassland. Different letters indicate significant differences among values.

An earlier soil seed bank study on the same grasslands at KCA reported a limited woody plant emergence (Gunaratne et al., 2010). They also showed that $85 \%$ of seedlings that emerged in the grasslands are confined to $<10 \mathrm{~m}$ from the forest edge. Similar scenario is also observed by a study in Columbia (Aide and Cavelier, 1994). In favour, the present study also showed similar results that plant abundance is highest at the FGE, but with less diversity compared to the Austroeupatorium- invaded open grassland communities (LIG and HIG). Higher woody seedling abundance at forest-pasture edges have been reported in a study south of Brazil (Fontoura et al., 2006) and elsewhere in the tropics (Kapos, 1989; Baldi, 1999). They attributed this trend to increased light intensities at the edge, as most woody species are light-demanding. However, in the present study, the edge vegetation is mostly dominated by shrub-, herbaceous and graminoid 
species, but not tree saplings. Several workers have also documented continuous alterations in plant community composition along forest edges (Gehlhausen et al., 2000; Fontoura et al., 2006).The vegetation studied across forestgrassland boundaries bordered by high- and lessinvaded grasslands registered a clear pattern of changes in the plant communities $10 \mathrm{~m}$ towards the forest interior and $10 \mathrm{~m}$ towards the open grassland, possibly influenced by the intensity of Austroeupatorium invasion. These changes across the forest-grassland boundaries are most evident with tree-, herb- and graminoid species than with shrub species. Tree sapling abundance and species richness increased towards the interior of the forests adjacent to highly-invaded grasslands. This again implies the positive influence of Austroeupatorium invasion on tree sapling establishment in these forest remnants at KCA. In both communities, FGE-LIG and FGEHIG, tree sapling density declined with increasing distance from the forest edge towards the open grassland. Similar observations have also been noted by several other workers (Ranney et al. 1981; Palik and Murphy 1990; Wales 1972; Brothers and Spingarn 1992; Brothers 1993; Fraver 1994). Our results showed that Austroeupatorium invasion favoured native species abundance in the open grassland. In contrast to present findings, Collier et al. (2002) showed that the native species abundance and richness decreased under the canopy of the invasive shrub, Lonicera maackii.

Austroeupatorium showed a gradual decline towards the forest interior and this observation was more conspicuous in the FGE-HIG community. Our results indicate that there is a potential for Austroeupatorium to invade into the forest, at least to a $10 \mathrm{~m}$ distance from the forest edge. This invasion potential is higher in grasslands bordered by HIG than by LIG. The short depth of penetration and abrupt decline in Austroeupatorium and other non-forest species in edge understorey vegetation suggest that the forest edge acts as a barrier for invasion to some extent. Brothers and Spingarn (1992) reported a similar observation in a study carried out in forest fragments of Central Indiana, USA, and suggest that the invasion is been discouraged by the dense wall of the bordering vegetation which reduces interior light levels and wind speed. Others also observed that invasion of non-forest species from an open field towards the forest is relatively low, suggesting that high density of vegetation cover at the forest edge could function as a physical barrier, limiting the arrival of wind-dispersed seeds into the forest (Cadenasso \& Picket 2001,
Honnay et al. 2002; Fontoura et al. 2006). However, Austroeupatorium being a lightdemanding shrub, has fewer chances to invade beyond $10 \mathrm{~m}$ within the forest interior.

The higher tree sapling abundance and species richness in the forest interior of the FGE-HIG, support the hypothesis that Austroeupatorium cover favors tree sapling establishment rather than suppressing it. Furthermore, we also observed a high negative correlation between the Austroeupatorium abundance and tress sapling abundance across the forest-grassland boundary at HIG $\left(\mathrm{R}^{2}=-0.94\right)$. This too substantiates the positive influence of Austroeupatorium cover on tree seedling abundance in these forest remnants contiguous with grasslands. Favourable microclimatic and edaphic conditions following Austroeupatorium invasion may be the driving force towards forest tree establishment in the forest interior as well in the open grassland. Shade and high soil moisture are considered as primary determinants for seedling establishment and survival according to a field experiment carried out in a Californian grassland (Kennedy and Sousa, 2006).

The present study showed that native species abundance was significantly higher in the open grassland, than in the edge and in the forest interior bordered by highly-invaded grasslands compared to the forests bordered by less-invaded grasslands. The light-demanding exotic species also showed a similar tendency in the open grassland. However, both natives and exotics showed higher species richness in the forest interior than at the edge and the open grassland, where the grasslands highly invaded by Austroeupatorium were richer than of the lessinvaded grasslands. This further supports that the Austroeupatorium invasion has some facilitative effect on native species establishment in the forest interior. Similar increases in species richness following invasions have been noted elsewhere in the world (Stohlgren et al., 1999; 2003). Leger (2008) too showed that native species tend to adapt in invaded communities through rapid and contemporary evolution, confirming their ability to evolve in response to the presence of invaders. Austroeupatorium invasion in the present study has altered the vegetation structure and composition of the immediate vicinity of these forest-grassland edges. Interestingly, endemic species abundance and richness were higher in the open grasslands less-invaded by Austroeupatorium than by HIG. The higher abundance of endemics in open grasslands than in the edge and the forest interior is mainly due to 
the presence of large population of Osbeckia octandra, an endemic shrub present in degraded areas exposed to light close to forest patches.

Forest encroachment into grasslands has been noted as a favoured mechanism in grassland restoration. Higher abundance of vegetation along the forest-grassland ecotone can protect tree seedlings from grazing, and also alter the surrounding environment to create a more suitable microhabitat for establishment. The main factor that favours tree species encroachment into Mediterranean grasslands has been identified as shrubs acting as 'safe sites' which are ideal areas for seed establishment (Kuntsler et al. 2007). Such facilitation can take place in different forms including resource modification, substrate modification, protection from herbivores and concentration of propagules for pollination (Callaway, 1995). Studies also have shown that shading of grassland plots has resulted in increased growth of seedlings of different species (Siemann and Rogers, 2003), while other studies conclude that shade alone is not sufficient for survival or increased growth of seedlings (Kennedy and Sousa, 2006). However, one of the most important mechanisms of facilitation is the alleviation of stressful microhabitat conditions (Callaway, 1995). Present results suggest that Austroeupatorium invasion has a facilitative effect on the tree seedling establishment in these highly degraded grasslands possibly through an enhanced shading effect or else through improved edaphic conditions, or both. As grasslands typically represent a very stressful environment for seedling establishment, facilitation is of critical importance during the early stage of succession (Kennedy and Sousa 2006). The present findings imply that the Austroeupatorium invasion has a facilitative effect towards seedling establishment not only in grasslands close to the forestgrassland edge, but also in the immediate forest interior, thus eventually catalyzing forest encroachment towards these highly degraded grasslands. Therefore, it is imperative to carefully consider the beneficial effects of invasive species on degraded lands, which could be used as a cost-effective restoration strategy to convert these grasslands back to forested land.

\section{REFERENCES}

Aide, T.M. and Cavellier, J. (1994). Barriers to lowland tropical forest restoration in the Sierra Nevada De Santa Marta, Colombia. Restoration Ecology 2: 219-229.
Baldi, A. (1999). Microclimate and vegetation edge effects in a reedbed in Hungary. Biodiversity and Conservation 8: 1697-1706.

Benitez-Malvido, J. (1998). Impacts of forest fragmentation on seedling abundance in a tropical rain forest. Conservation Biology 12: 380-389.

Borgmann, K.L. and Rodewald, A.D. (2005). Forest restoration in urbanizing landscapes: interactions between land uses and an exotic shrub. Restoration Ecology 13: 334-340.

Brothers, T. S. (1993). Fragmentation and edge effects in central Indiana old growth forests. Journal of Natural Areas 13: 268-275.

Brothers, T.S. and Spingarn, A. (1992). Forest fragmentation and alien plant invasion of central Indiana old-growth forests. Conservation Biology 6: 91-100.

Cadenasso, M.L. and Pickett, S.T.A. (2001). Effect of edge structure on the flux of species into forest interiors. Conservation Biology 15: 91-97.

Callaway, R.M. (1995). Positive interactions among plants. Botanical Review 61: 306-349

Collier, M.H., Vankat, J.L. and Hughes, M.R. (2002). Diminished plant richness and abundance below Lonicera maackii, an Invasive Shrub. American Midland Naturalist 147(1): 60-71.

Devlaeminck, R., Bossuyt, B. and Hermy, M. (2005). Inflow of seeds through the forest edge: evidence from seed bank and vegetation patterns. Plant Ecology 176: 1-17.

Fontoura, S.B., Ganade, G. and Larocca, J. (2006). Changes in plant community diversity and composition across an edge between Araucaria forest and pasture in South Brazil. Revista Brasileira de Botanica 29(1): 79-91.

Fraver, S. (1994). Vegetation responses along edge-to-interior gradients in the mixed hardwood forests of the Roanoke River basin, North Carolina. Conservation Biology 8: 822-832.

Gascon, C., Williamson, G.B. and da Fonseca, G.A.B. (2000). Receding forest edges and vanishing reserves. Science 288: 1356-1358.

Gehlhausen, S.M., Schwartz, M.W. and Augspurger, C.K. (2000). Vegetation and microclimatic edge effects in two mixedmesophytic forest fragments. Plant Ecology 147: 21-35.

Gunaratne, A. M. T. A., Alexander, I. J., Gunatilleke, C. V. S., Gunatilleke, I. A. U. N., Madawala Weerasinghe, H.M.S.P. and Burslem, D. F. R. P. (2010). Barriers to tree seedling emergence on human-induced grasslands in Sri Lanka. Journal of Applied 
Ecology 47(1): 157-165.

Harper, K.A. and Macdonald, S.E. (2002). Structure and composition of edges next to regenerating clear-cuts in mixed-wood boreal forest. Journal of Vegetation Science 13: 535546.

Honnay, O., Verheyen, K. and Hermy, M.(2002). Permeability of ancient forest edges for weedy plant species invasion. Forest Ecology and Management 161: 109-122.

Harper, K.A., Macdonald, S.E., Burton, P.J., Chen, J., Brosofske, K.D., Saunders, S.C., Euskirchen, E.S., Roberts, D., Jaiteh, M.S., Esseen, P. A., 2005. Edge influence on forest structure and composition in fragmented landscapes. Conservation Biology 19: 768782.

Hobbs, R.J. and Huenneke L.F. (1992). Disturbance, diversity, and invasion: implications for conservation. Conservation Biology 6: 324- 337.

Hsu, T.W., Peng, C.I. and Wang, C.M. (2006). Austroeupatorium inulifolium (Kunth) King \& Robinson (Asteraceae), a Newly Naturalized Plant in Taiwan. Taiwania 51(1): 41-45.

Jacquemyn, H., Butaye, J. and Hermy, H. (2001). Forest plant species richness in small, fragmented mixed deciduous forest patches: role of area, time and dispersal limitation. Journal of Biogeography 28: 1-12.

Kapos, V. (1989). Effects of isolation on the water status of forest patches in the Brazilian Amazon. Journal of Tropical Ecology 5: 173185.

Kennedy, P.G. and Sousa, W.P. (2006). Forest encroachment into a Californian grassland: examining the simultaneous effects of facilitation and competition on tree seedling recruitment. Oecologia 148(3): 464-74.

King, S.A. and Buckney, R.T. (2001). Exotic plants in the soil-stored seed bank of urban bushland. Australian Journal of Botany 49: 717-720.

Kunstler, G., Thuiller, W., Curt, T., Bouchaud, M., Jouviel, R., Deruette, L. and Lepart, J. (2007). Fagus sylvatica L. recruitment across a fragmented Mediterranean Landscape, importance of long distance effective dispersal, abiotic conditions and biotic interactions. Journal of Diversity and Distributions, 13: 799-807.

Laurance, W.F. (2000). Do edge effects occur over large spatial scales? Trends in Ecology and Evolution 15: 134-135.

Leger, E.A. 2008. The Adaptive Value of Remnant Native Plants in Invaded Communities: An Example from the Great
Basin. Ecological Applications 18(5): 12261235.

Laurance, W.F., Lovejoy, T.E., Vasconcelos, H.L., Bruna, E.M., Didham, R.K., Stouffer,

P.C., Gascon, C., Bierregaard, R.O., Laurance, S.G., Sampaio, E. (2002). Ecosystem decay of Amazonian forest fragments: a 22-year investigation. Conservation Biology 16: 605618.

Lin, L. and Cao, M. (2009). Edge effects on soil seed banks and understory vegetation in subtropical and tropical forests in Yunnan, SW China. Forest Ecology and Management 257: 1344-1352.

Lovejoy, T., Bierregaard, R., Rylands, J., Malcolm, J., Quintela, C., Harper, L., Brown, K., Powell, A., Powell, G., Schubart, H. and Hays, M. (1986). Edge and other effects of isolation on Amazon forest fragments. In: M. Soul6 (Editor), Conservation Biology. The Science of Scarcity and Diversity. Sinauer, Sunderland, MA, pp. 257-285.

Lugo, A.E. (2004). The outcome of alien tree invasions in Puerto Rico. Frontiers in Ecology and Environment 2(5): 265-273.

Murcia, C. (1995). Edge effects in fragmented forests: implications for conservation. Trends in Ecology and Evolution 10: 58-62.

Oosterhoorn, M. and Kappelle, M. (2000). Vegetation structure and composition along an interior-edge-exterior gradient in a Costa Rican montane cloud forest. Forest Ecology and Management 126: 291-307.

Palik, B.J. and Murphy, P.G. (1990). Disturbance versus edge effects in sugar-maple/beech forest fragments. Forest Ecology and Management 32:187-202.

Pauchard, A. and Alaback, P.B. (2006). Edge type defines alien plant species along Pinus contorta burned, highway and clear-cut forest edges. Forest Ecology and Management 223: 327-335.

Parrotta, J.A. and Turnbull, J.W. (1997). Catalyzing native regeneration on degraded tropical lands. Forest Ecology and Management 99: 1-290.

Ragubanshi, A.S. and Tripathi, A. (2009). Effect of disturbance, habitat fragmentation and alien invasive plants on floral diversity in dry tropical forests of Vindhyan highland: a review. Tropical Ecology 50(1): 57-69.

Ranney, J.W., Bruner, M.C. and Levenson, J.B. (1981). The importance of edge in the structure and dynamics of forest islands. In: R.L. Burgess and D.M. Sharpe (eds.), Forest Island Dynamics in Man Dominated Landscapes. Springer, New York. pp. 67-95.

Stohlgren, T. J., Binkley, D., Chong, G. W., 
Kalkahan, M. A., Schell, L. D., Bull, K. A., Otsuki, Y., Newman, G., Bashkin, M. and Son, Y. (1999). Exotic plant species invade hot spots of native plant diversity. Ecological Monographs 69: 25-46.

Stohlgren, T. J., Barnett, D. T. and Kartesz, J. T. (2003). The rich get richer: patterns of plant invasions in the United States. Frontiers in Ecology and the Environment 1:11-14.

Saunders, D.A., Hobbs, R.J. and Margules, C.R. (1991). Biological consequences of ecosystem fragmentation: a review. Conservation Biology 5: 18-32.

Siemann, E. and Rogers, W.E. (2003). Increased competitive ability of an invasive tree may be limited by an invasive beetle. Ecological
Applications 13: 1503-1507.

Sharma, G.P. (2007). Habitat Fragmentation Induced Species Invasion in Vindhyan Highlands. Ph.D. Thesis, Banaras Hindu University, Varanasi, India.

Vitousek, P.M., Mooney, H.A., Lubchenco, J. and Melillo, J.M. (1997). Human Domination of Earth's Ecosystems. Science 277: 494-499.

Wales, B.A. (1972). Vegetation analysis of north and south edges in a mature oak-hickory forest. Ecological Monographs 42: 451-471.

Watkins R.Z., Chen J.Q., Pickens J. and Brosofske K.D. (2003). Effects of forest roads on understory plants in a managed hardwood landscape. Journal of Conservation Biology 17: $411-419$.

Appendix 1. List of species sampled in 3 plant communities (LIG, HIG and FGE) in the Study 1 and the 2 plant communities (FGE-LIG and FGE-HIG) in Study 2 at Knuckles Conservation Area. Life forms represent: forest trees (TR), shrubs (SH), herbs (HB), climbers (CL), runners (RN), grasses (GR), sedges $(\mathrm{SG})$ and ferns $(\mathrm{FN})$. The endemic $(*)$, native $(\boldsymbol{q})$ and exotic (\#) status of species.

\begin{tabular}{|c|c|c|c|c|c|c|}
\hline \multirow{2}{*}{ Family/Species } & \multirow{2}{*}{$\begin{array}{l}\text { Life } \\
\text { form }\end{array}$} & \multicolumn{3}{|c|}{$\begin{array}{l}\text { Communities in } \\
\text { Study } 1\end{array}$} & \multicolumn{2}{|c|}{$\begin{array}{l}\text { Communities in } \\
\text { Study } 2\end{array}$} \\
\hline & & LIG & HIG & FGE & $\begin{array}{l}\text { FGE- } \\
\text { LIG }\end{array}$ & FGE-HIG \\
\hline \multicolumn{7}{|l|}{ APIACEAE } \\
\hline${ }^{\natural}$ Centella asiatica & RU & $\sqrt{ }$ & $\sqrt{ }$ & $\sqrt{ }$ & - & $\sqrt{ }$ \\
\hline \multicolumn{7}{|l|}{ ASTERACEAE } \\
\hline${ }^{\#}$ Austroeupatorium inulifolium & $\mathrm{SH}$ & $\sqrt{ }$ & $\sqrt{ }$ & $\sqrt{ }$ & $\sqrt{ }$ & $\sqrt{ }$ \\
\hline "Elephantopus scaber & $\mathrm{HB}$ & $\sqrt{ }$ & - & - & $\sqrt{ }$ & $\sqrt{ }$ \\
\hline "Mikania micrantha & $\mathrm{CL}$ & $\sqrt{ }$ & $\sqrt{ }$ & - & $\sqrt{ }$ & $\sqrt{ }$ \\
\hline${ }^{\circledR}$ Psiadia ceylanica & $\mathrm{SH}$ & $\sqrt{ }$ & - & $\sqrt{ }$ & $\sqrt{ }$ & $\sqrt{ }$ \\
\hline IVernonia cinerea & $\mathrm{HB}$ & - & - & - & $\sqrt{ }$ & $\sqrt{ }$ \\
\hline Vernonia sp. & $\mathrm{HB}$ & $\sqrt{ }$ & - & - & - & - \\
\hline \multicolumn{7}{|l|}{ CHLORANTHACEAE } \\
\hline $\begin{array}{l}\text { "Sarcandra chloranthoides } \\
\text { COMMELINACEAE }\end{array}$ & $\mathrm{TR}$ & - & - & - & $\sqrt{ }$ & $\sqrt{ }$ \\
\hline${ }^{\top}$ Commelina clavata & $\mathrm{CL}$ & $\sqrt{ }$ & $\sqrt{ }$ & - & $\sqrt{ }$ & $\sqrt{ }$ \\
\hline \multicolumn{7}{|l|}{ CONVOLVULACEAE } \\
\hline $\begin{array}{l}\text { Ipomoea } \text { sp. } \\
\text { CYPERACEAE }\end{array}$ & $\mathrm{CL}$ & - & $\sqrt{ }$ & - & - & - \\
\hline Cyperus sp. & SG & $\sqrt{ }$ & $\sqrt{ }$ & - & - & $\sqrt{ }$ \\
\hline${ }^{\top}$ Fimbristylis falcate & SG & - & - & $\sqrt{ }$ & - & - \\
\hline \multicolumn{7}{|l|}{ DIOSCOREACEAE } \\
\hline *Dioscorea koyamae & $\mathrm{CL}$ & - & - & - & $\sqrt{ }$ & $\sqrt{ }$ \\
\hline $\begin{array}{l}\text { ELAEGNACEAE } \\
\text { "Elaegnus latifolia }\end{array}$ & TR & - & $\sqrt{ }$ & - & $\sqrt{ }$ & $\sqrt{ }$ \\
\hline
\end{tabular}




\begin{tabular}{|c|c|c|c|c|c|c|}
\hline \multirow{2}{*}{ Family/Species } & \multirow{2}{*}{$\begin{array}{l}\text { Life } \\
\text { form }\end{array}$} & \multicolumn{3}{|c|}{$\begin{array}{c}\text { Communities in } \\
\text { Study } 1\end{array}$} & \multicolumn{2}{|c|}{$\begin{array}{c}\text { Communities in } \\
\text { Study } 2\end{array}$} \\
\hline & & LIG & HIG & FGE & $\begin{array}{l}\text { FGE- } \\
\text { LIG }\end{array}$ & FGE-HIG \\
\hline \multicolumn{7}{|l|}{ EUPHORBIACEAE } \\
\hline ๑Drypetes sepiaria & TR & - & - & - & $\sqrt{ }$ & $\sqrt{ }$ \\
\hline Euphorbia rothiana & $\mathrm{HB}$ & - & - & - & - & $\sqrt{ }$ \\
\hline "Flueggea leucopyrus & $\mathrm{SH}$ & - & - & - & $\sqrt{ }$ & - \\
\hline${ }^{\top}$ Mallotus philippensis & TR & - & - & - & $\sqrt{ }$ & - \\
\hline${ }^{\top}$ Mallotus tetracoccus & $\mathrm{TR}$ & - & - & - & - & $\sqrt{ }$ \\
\hline${ }^{\top}$ Macaranga peltata & $\mathrm{TR}$ & - & $\sqrt{ }$ & - & - & $\sqrt{ }$ \\
\hline Unidentified sp. & HB & $\sqrt{ }$ & $\sqrt{ }$ & - & - & - \\
\hline \multicolumn{7}{|l|}{ FABACEAE } \\
\hline${ }^{\circledR}$ Atylosia trinervia & $\mathrm{SH}$ & - & - & $\sqrt{ }$ & - & - \\
\hline "Desmodium triflorum & $\mathrm{HB}$ & $\sqrt{ }$ & $\sqrt{ }$ & $\sqrt{ }$ & - & $\sqrt{ }$ \\
\hline "Desmodium laxum & $\mathrm{HB}$ & - & $\sqrt{ }$ & - & - & $\sqrt{ }$ \\
\hline${ }^{\#}$ Mimosa pudica & $\mathrm{HB}$ & - & - & $\sqrt{ }$ & $\sqrt{ }$ & $\sqrt{ }$ \\
\hline${ }^{\#}$ Mimosa pigra & $\mathrm{SH}$ & $\sqrt{ }$ & $\sqrt{ }$ & - & - & - \\
\hline \multicolumn{7}{|l|}{ GLEICHENIACEAE } \\
\hline${ }^{\top}$ Gleichenia sp. & $\mathrm{FN}$ & $\sqrt{ }$ & - & - & $\sqrt{ }$ & $\sqrt{ }$ \\
\hline \multicolumn{7}{|l|}{ LAURACEAE } \\
\hline *Actinodaphne stenophylla & TR & - & - & - & $\sqrt{ }$ & $\sqrt{ }$ \\
\hline *Cinnamomum sp. & $\mathrm{TR}$ & - & - & - & - & $\sqrt{ }$ \\
\hline *Litsea glaberrima & TR & - & - & - & - & $\sqrt{ }$ \\
\hline \multicolumn{7}{|l|}{ LYCOPODIACEAE } \\
\hline${ }^{\circledR}$ Lycopodium clavatum & $\mathrm{FN}$ & $\sqrt{ }$ & - & - & - & - \\
\hline \multicolumn{7}{|l|}{ MALVACEAE } \\
\hline "Sida cordifolia & HB & - & $\sqrt{ }$ & - & - & - \\
\hline \multicolumn{7}{|l|}{ MENISPERMACEAE } \\
\hline${ }^{\circledR}$ Cyclea peltata & $\mathrm{CL}$ & - & $\sqrt{ }$ & - & $\sqrt{ }$ & $\sqrt{ }$ \\
\hline $\begin{array}{l}\text { `Stephania japonica } \\
\text { MELASTOMATACEAE }\end{array}$ & $\mathrm{CL}$ & & & & $\sqrt{ }$ & $\sqrt{ }$ \\
\hline *Osbeckia octandra & $\mathrm{SH}$ & $\sqrt{ }$ & $\sqrt{ }$ & $\sqrt{ }$ & $\sqrt{ }$ & $\sqrt{ }$ \\
\hline \multicolumn{7}{|l|}{ MORACEAE } \\
\hline IFicus hispida & TR & & & & - & $\sqrt{ }$ \\
\hline \multicolumn{7}{|l|}{ MYRSINACEAE } \\
\hline${ }^{\top}$ Maesa indica & TR & - & $\sqrt{ }$ & - & - & - \\
\hline \multicolumn{7}{|l|}{ MYRTACEAE } \\
\hline Psidium guineense & $\mathrm{SH} / \mathrm{TR}$ & - & - & - & $\sqrt{ }$ & $\sqrt{ }$ \\
\hline \multicolumn{7}{|l|}{ OLEACEAE } \\
\hline IJasminum angustifolium & $\mathrm{CL}$ & - & $\sqrt{ }$ & - & $\sqrt{ }$ & $\sqrt{ }$ \\
\hline \multicolumn{7}{|l|}{ OXALIDACEAE } \\
\hline${ }^{\#}$ Oxalis corniculata & $\mathrm{HB}$ & - & $\sqrt{ }$ & - & - & $\sqrt{ }$ \\
\hline
\end{tabular}




\begin{tabular}{|c|c|c|c|c|c|c|}
\hline \multirow{2}{*}{ Family/Species } & \multirow{2}{*}{$\begin{array}{l}\text { Life } \\
\text { form }\end{array}$} & \multicolumn{3}{|c|}{$\begin{array}{c}\text { Communities in } \\
\text { Study } 1\end{array}$} & \multicolumn{2}{|c|}{$\begin{array}{c}\text { Communities in } \\
\text { Study } 2\end{array}$} \\
\hline & & LIG & HIG & FGE & $\begin{array}{l}\text { FGE- } \\
\text { LIG }\end{array}$ & FGE-HIG \\
\hline \multicolumn{7}{|l|}{ PALMAE } \\
\hline "Calamus pseudotenuis & $\mathrm{CL}$ & - & $\sqrt{ }$ & - & $\sqrt{ }$ & $\sqrt{ }$ \\
\hline \multicolumn{7}{|l|}{ PINACEAE } \\
\hline \#Pinus sp. & $\mathrm{TR}$ & - & - & - & $\sqrt{ }$ & - \\
\hline \multicolumn{7}{|l|}{ POACEAE } \\
\hline \#Axonopus compressus & GR & $\sqrt{ }$ & $\sqrt{ }$ & $\sqrt{ }$ & $\sqrt{ }$ & $\sqrt{ }$ \\
\hline "Cymbopogon nardus & GR & $\sqrt{ }$ & $\sqrt{ }$ & $\sqrt{ }$ & $\sqrt{ }$ & $\sqrt{ }$ \\
\hline \#Panicum maximum & GR & - & $\sqrt{ }$ & - & - & - \\
\hline Grass sp. & GR & - & $\sqrt{ }$ & - & - & - \\
\hline \multicolumn{7}{|l|}{ POLYGALACEAE } \\
\hline Polygala sp. & $\mathrm{HB}$ & $\sqrt{ }$ & $\sqrt{ }$ & - & - & - \\
\hline \multicolumn{7}{|l|}{ POLYPODIACEAE } \\
\hline${ }^{\top}$ Cyclosorus sp. & FN & - & - & - & $\sqrt{ }$ & $\sqrt{ }$ \\
\hline${ }^{\top}$ Nephrolepis sp. & FN & $\sqrt{ }$ & - & $\sqrt{ }$ & $\sqrt{ }$ & $\sqrt{ }$ \\
\hline \multicolumn{6}{|l|}{ RUBIACEAE } & - \\
\hline "Catunaregam spinosa & $\mathrm{TR}$ & - & - & - & $\sqrt{ }$ & $\sqrt{ }$ \\
\hline "Hedyotis sp. & $\mathrm{HB}$ & - & $\sqrt{ }$ & - & - & $\sqrt{ }$ \\
\hline *Knoxia spicata & SH & $\sqrt{ }$ & - & - & $\sqrt{ }$ & $\sqrt{ }$ \\
\hline *Psychotria gardneri & $\mathrm{TR} / \mathrm{SH}$ & - & - & - & - & $\sqrt{ }$ \\
\hline \multicolumn{7}{|l|}{ RUTACEAE } \\
\hline "Acronychia pedunculata & $\mathrm{TR}$ & - & - & - & $\sqrt{ }$ & - \\
\hline${ }^{\top}$ Murraya koenigii & $\mathrm{TR}$ & - & - & - & $\sqrt{ }$ & - \\
\hline \multicolumn{7}{|l|}{ ROSACEAE } \\
\hline ףRubus gardnerianus & $\mathrm{CL}$ & - & - & - & $\sqrt{ }$ & $\sqrt{ }$ \\
\hline \multicolumn{7}{|l|}{ SYMPLOCACEAE } \\
\hline "Symplocos cochinchinensis & $\mathrm{TR}$ & - & $\sqrt{ }$ & - & - & $\sqrt{ }$ \\
\hline \multicolumn{7}{|l|}{ THEACEAE } \\
\hline \#Camellia sinensis & $\mathrm{TR}$ & - & - & $\sqrt{ }$ & - & $\sqrt{ }$ \\
\hline ₫Eurya nitida & $\mathrm{TR}$ & - & - & - & $\sqrt{ }$ & $\sqrt{ }$ \\
\hline \multicolumn{7}{|l|}{ VERBENACEAE } \\
\hline "Stachytarpheta indica & $\mathrm{HB}$ & $\sqrt{ }$ & $\sqrt{ }$ & $\sqrt{ }$ & $\sqrt{ }$ & $\sqrt{ }$ \\
\hline "Lantana camara & SH & - & $\sqrt{ }$ & - & $\sqrt{ }$ & $\sqrt{ }$ \\
\hline \multicolumn{7}{|l|}{ VITACEAE } \\
\hline${ }^{*}$ Cissus gardneri & $\mathrm{CL}$ & - & - & - & $\sqrt{ }$ & $\sqrt{ }$ \\
\hline \multicolumn{7}{|l|}{ ZINGIBERACEAE } \\
\hline "Eletaria caramomum & $\mathrm{SH}$ & - & - & - & - & $\sqrt{ }$ \\
\hline
\end{tabular}

